\title{
MENJADIKAN PUISI DAN DONGENG SEBAGAI SALAH SATU MEDIA PENDIDIKAN KARAKTER SISWA DI SDN 08 GANTING PADANGPANJANG
}

\author{
Desi Susanti1), Saaduddin²) \\ 1)2)Program Studi Seni Teater-Fakultas Seni Pertunjukan Institut Seni Indonesia Padangpanjang \\ Jl. Bahder Johan. Padangpanjang. Sumatera Barat \\ Email : desisusantiisipp@gmail.com ${ }^{1)}$,hanyadidin@gmail.com ${ }^{2)}$,
}

\begin{abstract}
ABSTRAK
Di era globalisasi, era teknologi televisi, gadget \& game yang menyuguhkan berbagai fitur yang menarik di mata anak-anak karena sifat keingi tahuan mereka ternyata sangat berpengaruh pada perkembangan pendidikan karakter anak-anak khususnya siswa SDN 08 Ganting yang beralamat di Jln Syech Ibrahim Musa Kota Padangpanjang. Sehingga Anak-anak di usia emas yang seharusnya menikmati pendidikan formal, bermain dan berkumpul dengan keluarga menjadi anak-anak yang asyik dan sibuk dengan teknologi televisi, gadget dan game. Menjadikan Puisi dan dongeng sebagai salah satu media pendidikan karakter adalah salah satu solusi untuk kembali merangkul anak-anak untuk menumbuhkan minat baca, daya imajinasi, dan intelijensi. Pelatihan Puisi dan Mendongeng ini nantinya akan dilakukan dengan menggunakan metode ceramah dan praktek, dengan demikian setelah pelatihan berakhir, anak-anak diharapkan mampu menguasai teknik membaca puisi dan mendongeng yang baik sehingga bisa bersaing di tingkat sekolah, daerah dan nasional. Hal ini sejalan dengan program pemerintah (literasi).
\end{abstract}

Kata kunci : Puisi, Dongeng, Pendikan Karakter, Siswa

\section{PENDAHULUAN}

Pendidikan adalah salah satu bidang yang sangat penting dalam kehidupan kita, karena dengan pendidikan masyarakat akan maju dan berkembang. Pendidikan juga berpengaruh terhadap perkembangan penduduk baik dibidang sosial budaya, cara berfikir maupun perekonomian ataupun bidang lainnya. Pada umumnya semakin masyarakat mempunyai pendidikan yang tinggi, maka akan semakin baik dan sejahtera masyarakat tersebut.

Dalam pelaksanaannya, pemerintah membentuk sistem pendidikan formal dan informal. Begitu juga halnya di Kelurahan Ganting terdapat beberapa sarana dan prasarana pendidikan, Salah satunya SDN 08 Ganting yang beralamat di jalan Syech Ibrahim Musa, Padangpanjang Timur, Kota Padangpanjang. Secara perekonomian masyarakat Kelurahan Ganting, Kecamatan Padangpanjang Timur, adalah tergolong masyarakat yang mempunyai ekonomi yang baik dan pada sisi lain komposisi tanah yang subur, maka mata pencarian masyarakatpun didominasi sebagai petani.

Secara sosio budaya masyarakat kelurahan Ganting didominasi oleh suku Minang, suku ini terkenal karena adatnya yang matrilineal. Sampai saat ini, adat masih dijadikan sebagai salah satu pertimbangan dalam pengambilan keputusan. Kearifan lokal yang telah diwariskan turun temurun masih cukup terjaga. Namun dampak globalisasi tidak dapat dielakkan. Untuk itu dibutuhkan kesinergian antara adat dan berbagai elemen lainnya.

Dari uraian diatas dapat disimpulkan bahwa pendidikan, perekonomian dan sosio budaya yang baik namun karena dampak globalisasi membawa pengaruh pada anak-anak sebagai penerus bangsa. Hal ini terjadi ketika kekuatan teknologi seperti televisi, gadget dan game yang fiturnya lebih menarik buat anak-anak, tentunya membawa pengaruh yang signifikan terhadap perkembangan dan pendidikan karakter anak-anak terutama siswa/I SDN 08 Ganting.

Pendidikan karakter merupakan bentuk kegiatan manusia yang di dalamnya terdapat suatu tindakan yang mendidik diperuntukan bagi generasi selanjutnya. Tujuan pendidikan karakter adalah untuk membentuk penyempurnaan dari individu secara terus menerus dan melatih kemampuan diri demi menuju kearah yang lebih baik (KBBI). Adapun nilai-nilai karakter 
berlandaskan budaya bangsa yaitu: 1). Religius, 2). Jujur, 3). Toleransi, 4). Disiplin, 5). Kerja keras, 6). Kreatif, 7). Mandiri, 8). Demokratis, 9). Rasa Ingin Tahu, 10). Semangat Kebangsaan, 11). Cinta tanah Air, 12). Menghargai prestasi, 13). Bersahabat/komunikatif, 14). Cinta damai, 15). Gemar membaca, 16). Peduli lingkungan. 17). Peduli Sosial, 18) Tanggung jawab.

Pendidikan karakter akan berlangsung dengan sia-sia, mana kala nilai-nilainya tidak dapat diimplementasikan dalam kehidupan sehari-hari. Sebagaimana diketahui bahwasanya pendidikan karakter lebih menekankan pada kebiasaan anak untuk melakukan hal-hal positif. Pengabdian masyarakat ini hadir untuk menjadikan puisi dan dongeng sebagai salah satu media pendidikan karakter siswa dan juga menumbuhkan minat baca sehingga anak-anak bisa menentukan pilihan dalam membentuk sebuah keperayaan diri dan karakternya. Memang butuh ketekunan dan kesabaran dalam menuntun anak-anak, namun Imajinasi juga lebih kuat dari pada pengetahuan, impian lebih kuat dari fakta, kata-kata terkenal Robert Fulghum ini menunjukkan pentingnya menghadirkan dunia imajinasi yang sehat bagi anak-anak. Terlebih ketika kita mengetahui betapa imajinasi anak kini semakin mengalami polusi. ditengah menjamurnya teknologi, seperti televisi, game dan gadget yang fiturnya lebih menarik dimata anak-anak. Hal ini menggiring kearah nilainilai yang jauh dari komitmen untuk membangun karakter dan kepribadian sehat, kukuh dan utuh.

SDN 08 Ganting yang terletak di jalan Syech Ibrahim Musa merupakan salah satu sekolah yang dipilih untuk menjadikan Puisi dan dongeng sebagai salah satu media pendidikan karakter siswa hal ini juga sejalan dengan keinginan yang sama dari pihak sekolah agar anak-anak bisa mengenal yang namanya puisi dan dongeng untuk mengembangkan bakat dan kreativitas serta menjadi pilihan untuk dipelajari siswa didik. Sehingga waktu anak-anak terisi dengan hal yang positif.

Meskipun puisi dan dongeng bisa dilihat anak melalui kaset, video namun teknologi audiovisual belum bisa menggantikan kekuatan bercerita dengan mendongeng dan puisi. Dalam menyampaikan isi cerita, tentu televisi mampu menarik perhatian anak karena dilakukan melalui visualisasi, tetapi yang lain ada yang hilang dan tak bisa digantikan, yaitu kesempatan berkomunikasi langsung dan kekuatan berdialog, selain komunikasi, puisi dan mendongeng juga menimbulkan kehangatan, dekapan dan pendekatan secara individual.

Melihat kondisi seperti tersebut di atas, maka pada masa globalisasi ini, menjadikan puisi dan dongeng sebagai salah satu media pendidikan karakter siswa perlu mendapat perhatian khususnya, terutama oleh ISI Padangpanjang sebagai salah satu Perguruan Tinggi Kesenian yang mengemban tugas menggali, membina, dan mengembangkan kesenian.

Sebagaimana yang tertuang dalam Tri-Dharma Perguruan Tinggi yaitu; 1) Perguruan Tinggi berfungsi sebagai pusat pendidikan; 2) Perguruan Tinggi berfungsi sebagai pusat penelitian; 3) Perguruan Tinggi berfungsi sosial melaksanakan pengabdian pada masyarakat. Dalam hal ini pengabdian pada masyarakat merupakan dharma ketiga dari Tri-Dharma Perguruan Tinggi dan merupakan salah satu tugas Perguruan Tinggi dalam hubungan tanggung jawabnya terhadap perkembangan dan kemajuan kelompok-kelompok masyarakat. Kegiatan pengabdian dilakukan dalam bentuk pelatihan untuk menjadikan puisi dan dongeng sebagai salah satu media pendidikan karakter siswa. Hal ini sejalan dengan kegiatan pemerintah yaitu penggiat literasi.

\subsection{Masalah Yang Dapat di Identifikasi}

Adapun masalah yang dapat diidentifikasi di SDN 08 Ganting Kelurahan Padangpanjang Timur, Kota Padangpanjang adalah sebagai berikut:

1. Menumbuhkan kegemaran anak-anak membaca pusi dan dongeng sehingga memunculkan anak-anak yang kreatif di SDN 08 khususnya puisi dan dongeng.

2. Membutuhkan tenaga yang profesional dalam bidang Pelatihan Puisi dan Dongeng

3. kurangnya apresiasi terhadap pentingnya Puisi dan dongeng sebagai salah satu media pendidikan karakter siswa sebagai salah satu aset daerah 


\section{METODE PELAKSANAAN}

\subsection{Pendekataan Yang Ditawarkan}

Melibatkan partisipasi pihak sekolah SDN 08 Ganting baik guru maupun siswa/i maupun para orang tua dimulai dari perencanaan, pelaksanaan dan melanjutkan kegiatan ini sesuai kesepakatan yang dirancang secara bersama-sama. Menjadikan puisi dan dongeng sebagai salah satu media pendidikan karakter dalam pengabdian pada masyarakat ini. Membentuk kerjasama/kemitraan dengan ISI Padang Panjang sebagai perguruan tinggi seni yang terletak di kota Padang Panjang dan menjembatani pertemuan dengan pihak pemerintah dan terkait dalam program pengabdian ini.

Prosedur kerja yang akan dilaksanakan dalam Pengabdian Pada Masyarakat ini adalah:

1. Sosialisasi kegiatan

Menjelaskan tentang Puisi dan dongeng sebagai pendidikan karakter siswa/siswi serta menumbuhkan minat baca pada siswa dan siswi ditengah era globalisasi sekarang ini. Memberikan Pelatihan dasar, olah tubuh, olah vocal dan olah rasa. Setelah informasi sampai pada siswa/i selanjutnya menjelaskan motivasi dari pengabdian pada masyarakat ini sehingga tecapai kesepakatan bersama. Membentuk kelompok kecil Puisi dan dongeng yang kemudian dibagi sesuai arah pelatihan. Masing-masing kelompok 10 - 15 orang setiap kelompoknya. Dan kelompok-kelompok inilah yang menjadi mitra nantinya untuk kerjasama.

2. Persiapan

Sebelum pelatihan Puisi dan dongeng dimulai, dibutuhkan persiapan yang matang agar segala proses kegiatan yang sudah direncanakan dapat terukur. Untuk itu beberapa masukan dan kebutuhan yang diharapkan pihak sekolah dan siswa didata yang kemudian disusun sebagai pedoman untuk skedul pertemuan-pertemuan kegiatan.

3. Pelatihan

Pelatihan dalam progam pengabdian pada masyarakat ini tentunya tidak bisa dilaksanakan setiap hari karena harus menyesuaikan dengan jadwal sekolah anak-anak yang menjadi peserta kegiatan ini dan jadwal kuliah tim pengabdian masyarakat, untuk itu seluruh kegiatan ini dibuatkan jadwal pelatihan yang mengacu pada musyawarah dan mufakat. Dalam hal ini penulis menyusun latihan 2 kali seminggu setiap hari Rabu Pukul 11.00 Wib s.d 13.00 Wib dan hari Sabtu Pukul 10.00 s.d 12.00 Wib selama rentang waktu 17 kali pertemuan pengabdian pada masyarakat. Adapun Metode yang digunakan dalam pelatihan ada 2 yaitu metode ceramah dan metode praktek.

4. Penampilan

Setelah proses pertemuan latihan dianggap maksimal dibutuhkan try out ataupun penampilan hasil latihan, agar apa yang disampaikan dapat terlihat manfaatnya. Penampilan ini juga bertujuan untuk memotivasi siswa dan siswi lainnya sekitar kelurahan Ganting untuk melakukan hal yang sama. Hasil dari pelatihan ini ditampilkan pada tanggal 16 Agustus 2018 dalam kegiatan Semarak Literasi Kemerdekaan di Perpustakaan daerah Padangapanjang

5. Seminar Internal

Seminar Internal dilakukan sebagai ruang evaluasi dalam upaya mencari masukan-masukan dan evaluasi terhadap kerja program pengabdian pada masyarakat ini. Seminar internal ini dilaksanakan bertempat di kantor LPPMPP ISI Padangpanjang dengan tim reviewer pada tanggal 17 September 2018.

6. Pelaporan

Setelah rangkaian kegiatan pengabdian pada masyarakat ini berakhir penulis menyusun laporan sebagai tanggung jawab penulis dalam melakukan kegiatan. Pelaporan tidak saja dalam bentuk tertulis namun juga dalam bentuk dokumentasi kegiatan.

7. Keberlanjutan

Program pengabdian pada masyarakat yang dijalankan ini tentunya memiliki banyak kelemahan-kelemahan sebagai sebuah awal kegiatan untuk itu penulis memerlukan keberlanjutan pada program ini. Adapun hal yang akan penulis lakukan dalam hal keberlanjutan ini tentunya perngembangan dari program awal seperti penggunaan property untuk dongeng. 


\subsection{Materi}

Tim pelaksana dalam kegiatan ini adalah Dosen dan Mahasiswa Prodi Seni Teater Fakultas Seni Pertunjukan yang tergabung dalam Lembaga Penelitian dan Pengabdian pada Masyarakat (LPPM) ISI Padang Panjang yang konsen pada bidang seni dan budaya dan telah melakukan beberapa penelitian, Karya Seni dan pengabdian pada masyarakat. Pengabdian pada masyarakat ini tidak terlepas dari peranan terkait, baik sesama dosen pemangku mata kuliah maupun mahasiswa yang dianggap mampu dalam bidangnya yang secara bersama-sama melakukan pengabdian ke tengah masyarakat.

Sesuai dengan masalah yang telah diidentifikasi maka dapat dilakukan kegiatan pengabdian sebagai berikut:

Tabel 1. Materi Pengabdian

\begin{tabular}{|c|l|l|}
\hline No & \multicolumn{1}{|c|}{ MATERI KEGIATAN } & \multicolumn{1}{|c|}{ REALISASI } \\
\hline 1. & $\begin{array}{l}\text { Menjelaskan tentang Puisi dan } \\
\text { Dongeng dan peran pentingnya } \\
\text { untuk dipelajari oleh siswa/I di SDN } \\
\text { 08 Ganting }\end{array}$ & $\begin{array}{l}\text { Meningkatkan pemahaman dan apresiasi para } \\
\text { peserta tentang Puisi dan Dongeng serta peran } \\
\text { pentingnya untuk dipelajari oleh siswa/I SDN 08 } \\
\text { Ganting. }\end{array}$ \\
\hline 2. & $\begin{array}{l}\text { Menjelaskan tentang Olah Tubuh, } \\
\text { Olah Vokal dan Olah Rasa sebagai } \\
\text { dasar dari pemahaman terhadap teks }\end{array}$ & $\begin{array}{l}\text { Meningkatkan pemahaman peserta akan pentingnya } \\
\text { pelatihan dasar olah tubuh, olah vocal dan olah rasa. }\end{array}$ \\
\hline 3 & $\begin{array}{l}\text { Memberikan penjelasan tentang } \\
\text { pelatihan Puisi dan Dongeng dengan } \\
\text { menggunakan tubuh, warna vocal } \\
\text { yang beragam dan emosi yang } \\
\text { berbeda setiap bagian }\end{array}$ & $\begin{array}{l}\text { Meningkatkan dan mengembangkan pelatihan Puisi } \\
\text { dan Dongeng pada siswa/i sehinga bisa } \\
\text { menggunakan tubuh, vocal dan emosi untuk } \\
\text { menciptakan sebuah karakter }\end{array}$ \\
\hline
\end{tabular}

\subsection{Metode}

Sehubungan hal di atas, untuk mencapai tujuan dari kegiatan ini, kelompok pengabdian tentunya menggunakan metode ceramah, diskusi dan Tanya jawab dan praktek dalam Menjadikan Puisi dan Dongeng sebagai salah satu media Pendidikan Karakter. Berikut ini dapat dilihat metode tersebut:

a. Metode ceramah dilakukan oleh seluruh para peserta pelatihan, dengan harapan agar semua peserta dapat memahami hal-hal yang berhubungan dengan Puisi dan Dongeng yang akan diajarkan.

b. Pelatihan/Praktek

Praktek pelatihan dilakukan dengan menggunakan metode:

1. Metode demonstrasi yaitu dengan mempraktekkan cara-cara dalam permainan yang telah ditentukan dengan mengajarkan tentang cara berdialog, ekspresi dan gesture dengan benar.

2. Metode Drill yaitu suatu metode yang diberikan kepada anggota/peserta agar materi yang sudah diajarkan diulang dirumah, sehingga anggota atau peserta mengguasai penampilan Puisi dan Dongeng yang telah diajarkan secara baik dan benar.

Pelatihan ini dilakukan dengan membagi para peserta menjadi 2 kelompok yaitu, (1) kelompok Puisi (2) Kelompok Dongeng.

Metode-metode yang digunakan dalam kegiatan pelatihan Menjadikan Puisi dan Dongeng Sebagai Salah Satu Media Pendidikan Karakter sebagaimana tersebut di atas, diharapkan dapat membantu tercapainya keterampilan dalam membaca Puisi dan Mendongeng dengan baik, yaitu keterampilan praktek yang disertai kesadaran dan pemahaman terhadap teks Puisi dan Dongeng.. Disamping itu, metode tersebut diharapkan dapat membantu kelompok pengabdian dalam proses pelatihan sehingga para peserta pelatihan merasa termotivasi, tidak bosan untuk belajar secara serius dan tertarik terhadap materi yang diajarkan. Dengan demikian para peserta bersemangat latihan, baik secara individu maupun berkelompok walaupun tanpa bimbingan langsung atau diluar jadwal kegiatan yang telah direncanakan, sebagaimana tercantum berikut ini: 
Tabel 2. Jadwal Pengabdian

\begin{tabular}{|c|c|c|}
\hline No. & HARI/TANGGAL & $\begin{array}{r}\text { MATERI } \\
\end{array}$ \\
\hline 1. & Rabu, 18 Juli 2018 & $\begin{array}{l}\text { Menjelaskan tentang Puisi dan Dongeng serta pentingnya untuk } \\
\text { dipelajari. }\end{array}$ \\
\hline 2 & Sabtu, 21 Juli 2018 & Menjelaskan dan Praktek olah tubuh, olah rasa dan olah vokal \\
\hline 3 & Rabu, 25 Juli 2018 & $\begin{array}{l}\text { Memberikan penjelasan tentang pelatihan Puisi dan Dongeng } \\
\text { dengan menggunakan gerak tubuh, warna vocal yang beragam } \\
\text { dan emosi yang berbeda setiap bagian }\end{array}$ \\
\hline 4. & Sabtu, 28 Juli 2018 & $\begin{array}{l}\text { Belajar imajinasi, (emosi ketika marah, sedih, senang dan lain- } \\
\text { lainnya) }\end{array}$ \\
\hline 5 & Rabu, 1 Agustus 2018 & $\begin{array}{l}\text { Mencari warna vokal untuk kebutuhan karakter tokoh dalam } \\
\text { dongeng dan warna vocal yang pas untuk teks puisi }\end{array}$ \\
\hline 6. & Sabtu, 4 Agustus 2018 & Reading teks puisi dan dongeng \\
\hline 7 & Rabu, 8 Agustus 2018 & Reading sesuai dengan teks yang dipilih dan evaluasi \\
\hline 8 & Sabtu, 11 Agustus 2018 & $\begin{array}{l}\text { Hafalan dengan irama, intonasi, tempo sesuai karakter tokoh } \\
\text { dan teks puisi }\end{array}$ \\
\hline 9 & Senin, 13 Agustus 2018 & $\begin{array}{l}\text { Hafalan sesuai dengan karakter tokoh dengan menggunakan } \\
\text { gerak tubuh, bloking, irama, tempo, emosi dan ekspresi. }\end{array}$ \\
\hline 10 & Rabu, 15 Agustus 2018 & $\begin{array}{l}\text { Lanjutan hafalan dengan karakter tokoh dengan menggunakan } \\
\text { gerak tubuh bloking, irama, tempo, emosi dan ekspresi. }\end{array}$ \\
\hline 11 & Kamis, 16 Agustus 2018 & $\begin{array}{l}\text { Pertunjukan dalam rangka Semarak Literasi Kemerdekaan di } \\
\text { Perpustakaan Daerah Padangpanjang. }\end{array}$ \\
\hline 12 & Sabtu, 18 Agustus 2018 & $\begin{array}{l}\text { Evaluasi hasil pertunjukan puisi dan dongeng yang sudah } \\
\text { dilakukan, Tim Pengabdian meminta siswa/i untuk terus } \\
\text { memahami tek dan berlatih di rumah. }\end{array}$ \\
\hline 13 & Sabtu, 25 Agustus 2018 & $\begin{array}{l}\text { Latihan dengan menggunakan bloking yang diarahkan oleh tim } \\
\text { pengabdian. } \\
\text { Latihan dengan menggunakan gerak tubuh, emosi, irama, } \\
\text { tempo dan ekspresi yang diarahkan oleh tim pengabdian. } \\
\text { Mengisi bagian yang masih kurang pada waktu pertunjukan }\end{array}$ \\
\hline 14 & Rabu, 29 Agustus 2018 & Latihan lanjutan \\
\hline 15 & Sabtu, 1 September 2018 & $\begin{array}{l}\text { Latihan dari awal sampai akhir dengan menggunakan gerak } \\
\text { tubuh, bloking, irama, tempo, ekspresi dan emosi sesuai dengan } \\
\text { teks }\end{array}$ \\
\hline 16 & Rabu, 5 September 2018 & $\begin{array}{l}\text { Pengulangan latihan dari awal sampai akhir dengan } \\
\text { menggunakan gerak tubuh, bloking, irama, tempo, ekspresi dan } \\
\text { emosi sesuai dengan teks } \\
\text { Masih ada yang perlu ditata dan di rapikan oleh tim pengabdian }\end{array}$ \\
\hline 17 & Sabtu, 8 September 2018 & $\begin{array}{l}\text { Penutupan dengan siswa dan pihak sekolah. } \\
\text { Pemberian sertifikat kepada siswa/siswi yang sudah tampil } \\
\text { pada acara Semarak Literasi Kemerdekaan }\end{array}$ \\
\hline
\end{tabular}

Berikut ini beberapa dokumentasi kegiatan Pengabdian Kepada Masyarakat di SDN 08 Ganting, Padangpanjang: 


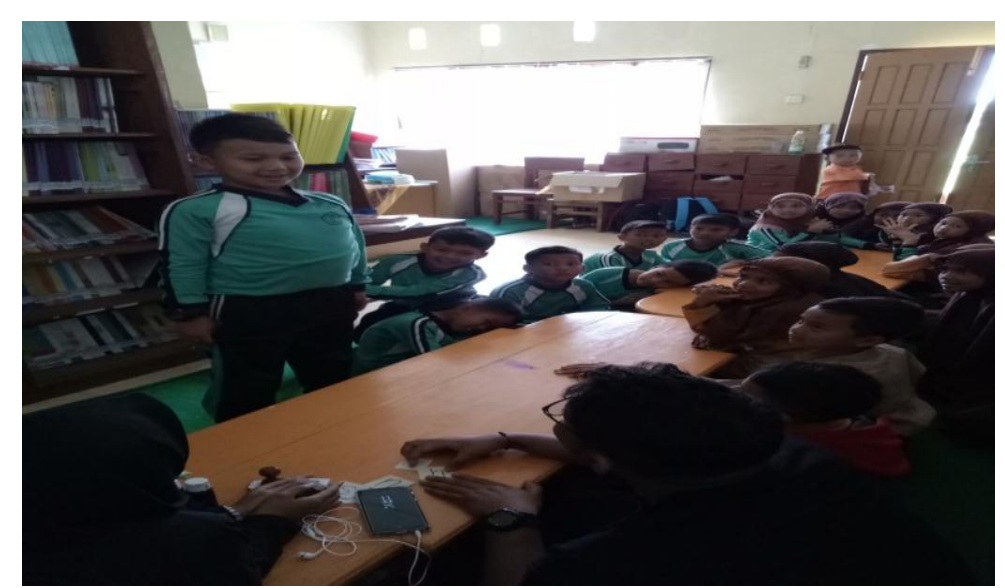

Gambar 1. Pertemuan Pertama, perkenalan dan memberi pemahaman tentang Puisi dan Dongeng kepada siswa/I SDN 08 Ganting, Padangpanjang

(Dok; Foto, Desi Susanti, 2018)

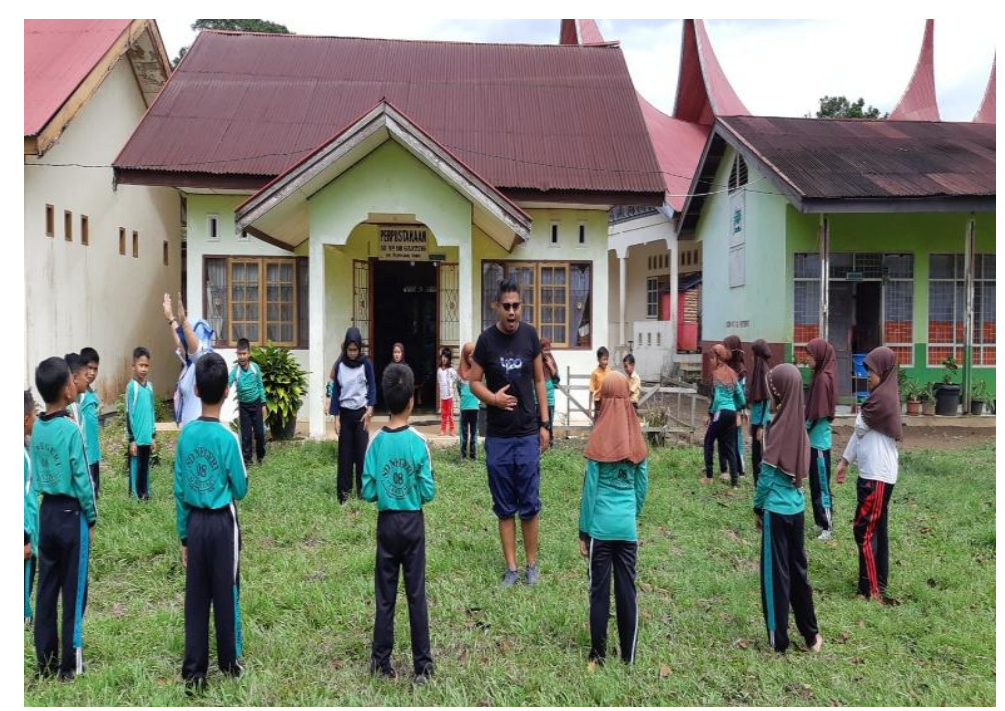

Gambar 2. Latihan Olah Tubuh, Olah Vokal dan Olah Rasa

(Dok; Foto, Desi Susanti, 2018)

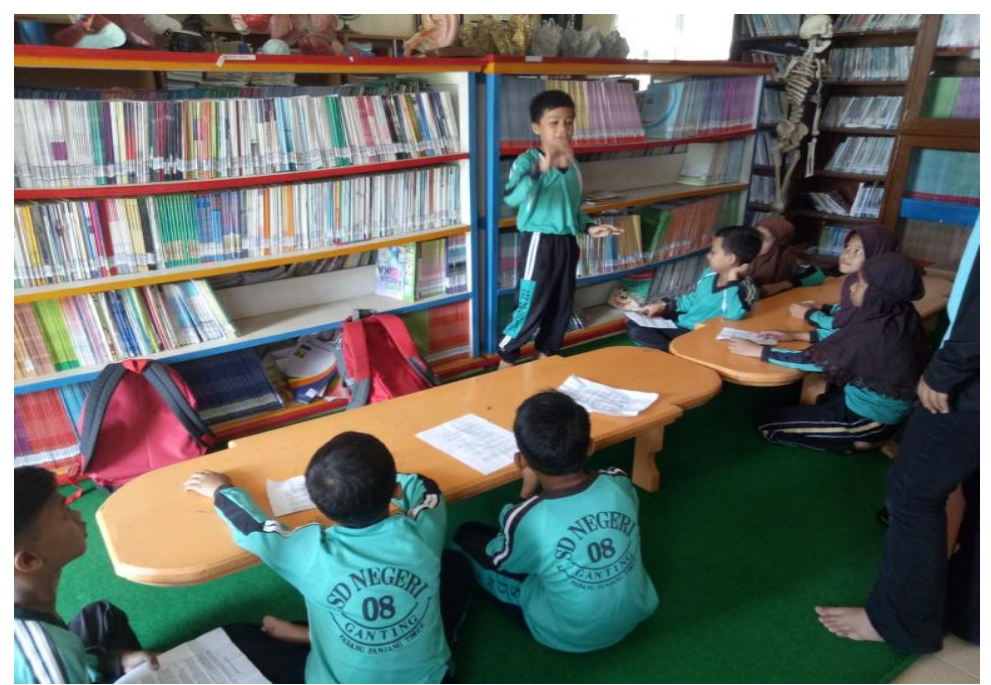

Gambar 3. Kelompok Mendongeng menirukan berbagai suara binatang sesuai dengan teks yang telah dipilih

(Dok; Foto, Desi Susanti, 2018) 


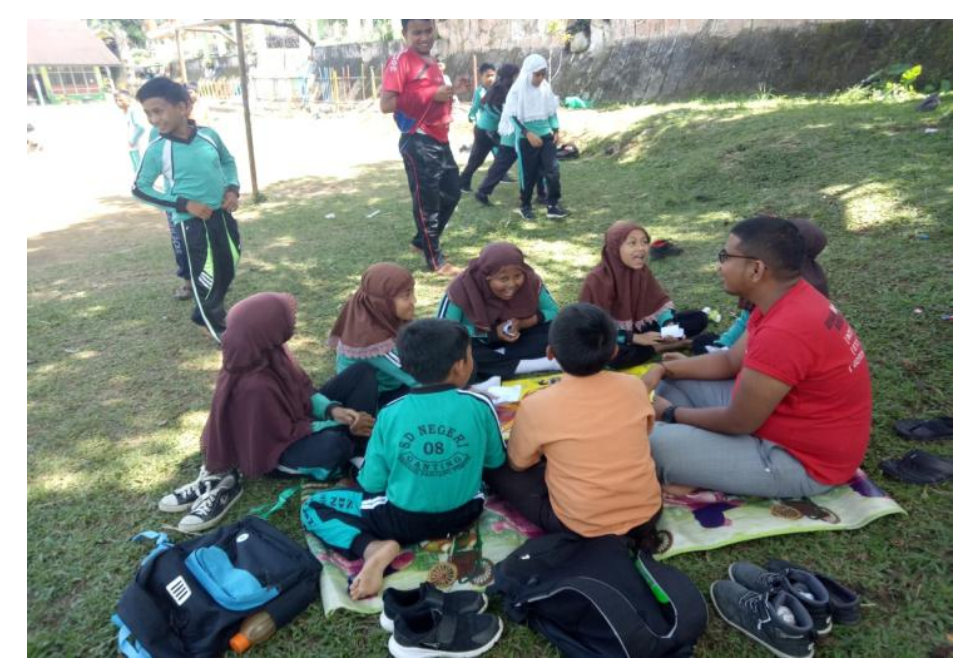

Gambar 4. Kelompok Puisi latihan dengan membaca teks secara bersamaan (Dok; Foto, Desi Susanti, 2018)

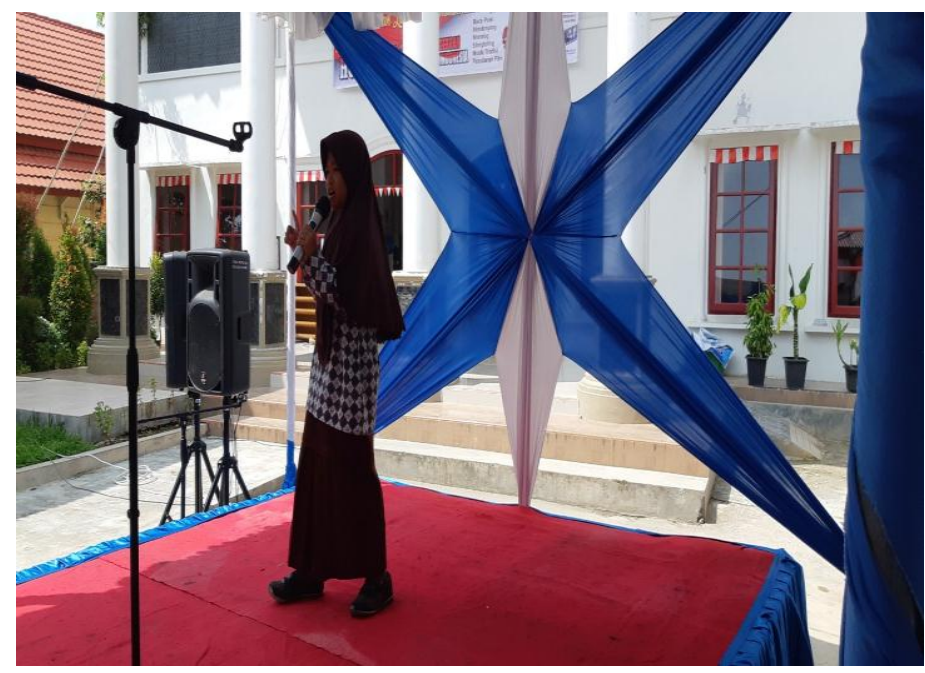

Gambar 5. Salah Satu Penampilan Dongeng siswa/I SDN 08 Ganting dalam kegiatan Semarak Literasi Kemerdekaan di Perpustakaan Daerah Padangpanjang (Dok; Foto, Desi Susanti, 2018)

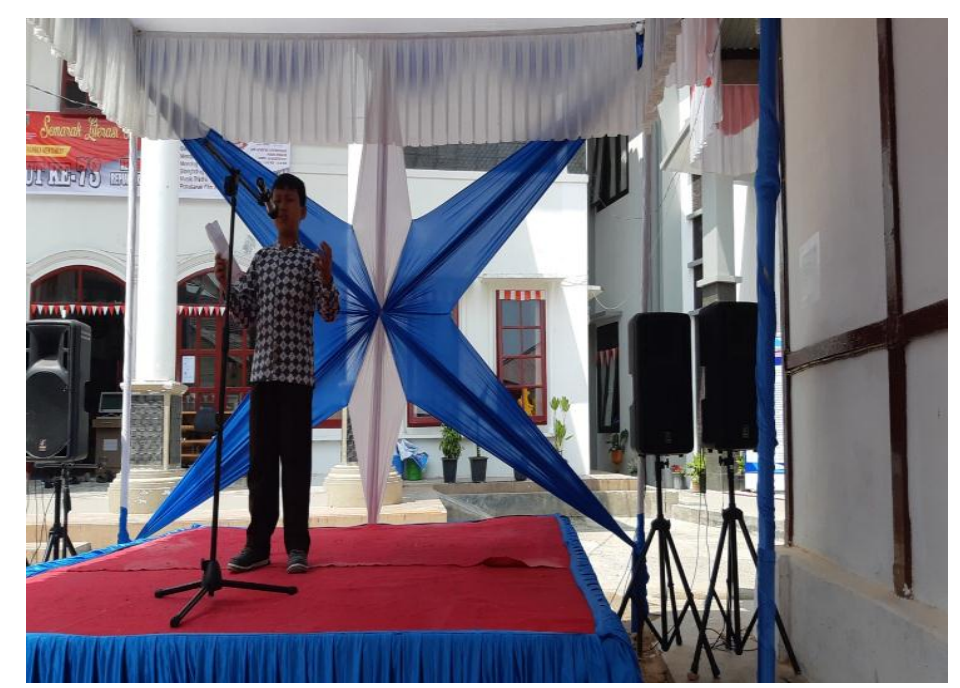

Gambar 6. Salah Satu Penampilan Membaca Puisi siswa/I SDN 08 Ganting dalam kegiatan Semarak Literasi Kemerdekaan di Perpustakaan Daerah Padangpanjang (Dok; Foto, Desi Susanti, 2018) 


\section{HASIL DAN PEMBAHASAN}

Hasil dari kegiatan menjadikan Puisi dan dongeng sebagai salah satu media pendidikan karakter siswa/i di SDN 08 Ganting Padangpanjang yang telah dilakukan adalah terbentuknya anak-anak yang mempunyai bakat dan minat dibidang seni khususnya puisi dan dongeng. Pada awal nya siswa/i di SDN 08 ini hanya sekedar tahu apa itu puisi dan apa itu dongeng tapi belum pernah mencoba untuk membacakannya sehingga anak-anak ini begitu semangat dan kreatif dalam mengikuti pelatihan.

Diawal pertemuan tim pengabdian sudah dapat melihat bahwa siswa/i yang ikut dalam pelatihan ini mempunyai bakat yang selama ini kurang mendapat perhatian dan tentunya belum ada yang melatih sesuai dengan kompetensi dibidangnya, bahkan ada siswa yang baru kelas 3 tapi sudah mempunyai cara sendiri untuk mengekspresikan bacaan teksnya.

Berhasilnya para siswa/i SDN 08 Ganting dalam menjadikan puisi dan dongeng sebagai salah satu media pendidikan karakter tidak lepas dari kerja sama yang baik antara tim pengabdian, pihak sekolah dan siswa/siswi yang memiliki karakter beraneka ragam dan unik. Dalam kegiatan ini tim pengabdian menyajikan dongeng pada siswa/i mempunyai niat optimis untuk bercerita pada anak, membuat atau menyiapkan cerita sesuai dengan tema-tema pilihan sesuai kebutuhan seperti keberanian, kejujuran, kemandirian, inisiatif, pantang menyerah, kebahagiaan dan lain-lain, berlatih vocal untuk memperkuat dan memperkaya vokal dialog maupun vokal ilustrasi, berlatih gerak untuk dongeng atraktif, gerakan-gerakan tubuh yang unik akan memancing imajinasi anak dan menarik perhatian anak sehingga dongeng tidak terlihat monoton dan membosankan. Tim Pengabdian harus kreatif dan berinovasi dalam memberikan contoh agar mudah dipahami oleh siswa/i. Selain itu Tim Pengabdian juga berhasil membuat dua buah cerita dongeng yang dimainkan oleh siswa/i. Adapun cerita dongeng yang dibuat tentang fabel yaitu merupakan cerita yang mengangkat binatang sebagai tokoh dan menceritakan tentang kehidupan mereka. Adapun judul dongengnya, Kisah Semut dan Kepompong dan Dongeng Asal Mula Rumah Siput. Sedangkan Puisi yang dipilih Aku karya Chairil Anwar, Tuhan, Kita Begitu Dekat karya Abdul Hadi dan Sajak Bagi Negaraku karya Kriapur.

\section{KESIMPULAN}

Berdasarkan pengalaman selama melakukan pelatihan untuk menjadikan puisi dan dongeng sebagai salah satu media pendidikan karakter di SDN 08 Ganting padangpanjang, ada beberapa aspek yang sangat berperan dalam pendidikan dan pembinaan siswa/i dalam membaca puisi dan dongeng antara lain pentingnya kebersamaan dan keinginan dari pihak sekolah untuk membuka diri terhadap seni khususnya dalam membaca puisi dan dongeng, serta adanya pelatih yang berkompeten dibidang tersebut. perhatian yang serius dari pihak sekolah dan wali murid serta masyarakat setempat, adanya keinginan dalam usaha mengasah kemampuan anak didik, dalam bentuk kemasan kesenian yang cukup sederhana sehingga mudah dipelajari bagi yang berminat mempelajarinya dan mampu menarik perhatian dan meningkatkan semangat siswa/i yang lainnya.

\section{Saran}

Berdasarkan kondisi yang ditemui, dapat diajukan beberapa saran agar menjadikan puisi dan dongeng sebagai salah satu media pendidikan karakter siswa/i di SDN 08 Ganting dapat terbina dan terpelihara dengan baik sebagai berikut:

1. Agar pihak sekolah menaruh perhatian yang serius terhadap pelatihan puisi dan dongeng maupun kesenian yang lainnya

2. Agar pihak yang berkompeten dibidang kesenian ini mau berbagi ilmu dengan ana-anak yang merupakan ujung tombak keberlanjutan seni itu sendiri sesuai dengan etika, dan moral adat dan agama.

3. Agar instansi terkait dapat memperhatikan kebutuhan-kebutuhan untuk pembinaan kesenian tersebut. 


\section{DAFTAR PUSTAKA}

Anirun, Suyatna. Menjadi Sutradara. Jakarta: STSI Press Bandung 2002.

Dewojati, Cahyaningrum.Drama Sejarah Teori dan Penerapannya. Gajah Mada University Press. 2010.

Sitorus, D Eka, The art of acting: Seni Peran Untuk Teater, Film dan TV, Jakarta: Gramedia Pustaka Utama, 2003.

Yudiaryani. Panggung Teater Dunia: Perkembangan dan Perubahan Konvensi. Yogyakarta:Pustaka Gondho Suli, 2002.

Batoboh, Jurnal Pengabdian Pada Masyarakat, Vol 3, No. 1 Maret 2018. 